\title{
Erratum: Distinct migration and contact dynamics of resting and IL-2-activated human natural killer cells
}

\section{Frontiers Production Office*}

Frontiers Production Office, Frontiers, Switzerland

*Correspondence: production.office@frontiersin.org

Approved by:

Immunology Editorial Office, Frontiers, Switzerland

Keywords: natural killer cells, cell migration, single-cell, fluorescence imaging, microchip

\section{An erratum on}

Distinct migration and contact dynamics of resting and IL-2-activated human natural killer cells

by Olofsson PE, Forslund E, Vanherberghen $B$, Chechet K, Mickelin O, Ahlin AR, Everhorn T and Öfelt B. Front Immunol (2014) 5:80. doi:10.3389/fimmu.2014.00080

\section{REASON FOR ERRATUM}

In the Section "Results" of the article, several numbers in the text were misinterpreted due to a typesetting error. This mistake does not change the scientific conclusions of the article in any way. The publisher apologizes for this error and the correct versions of the relevant paragraphs appear below.

The corrected values are in bold.

\section{RESULTS \\ ACTIVATED NK CELLS EXHIBIT MORE DYNAMIC MIGRATION, WHICH IS RELATED TO MODES OF MIGRATION}

The average mean migration speed of the resting $\mathrm{NK}$ cells over the 8 -h assay was $1.6 \pm 0.6 \mu \mathrm{m} / \mathrm{min}$, while it was $1.7 \pm 0.7 \mu \mathrm{m} / \mathrm{min}$ for activated NK cells $(p<0.005)$. A histogram of mean migration speeds revealed substantial differences in the mean speeds of individual cells within subsets and that fast-migrating NK cells were more common in the activated subset (Figure 1A).

We then set out to investigate if there were any detectable differences in the migration behavior of activated and resting NK cells. To this end, we applied a previously developed method to subdivide cell trajectories into three distinct modes of migration, i.e., TMAPs, directed migration, or random movement (21). Overall, a majority of NK cells spent considerable time in TMAPs with the average fractions of time $89 \%$ for resting and $71 \%$ for activated NK cells (Figure 1B). Strikingly, approximately $72 \%$ of resting NK cells spent between 90 and 100\% of the assay in TMAPs compared to $38 \%$ for the activated NK cells (Figure 1C). Thus, a large fraction of the resting cells displayed low motility while activated NK cells were significantly more motile $(p<0.005)$.

Examining directionally persistent migration showed that all resting NK cells (with the exception of one cell) spent little time in directed migration $(<40 \%$ of the time), while a few activated NK cells spent $>40 \%$ of the assay in directed migration (Figure 1D). The average times spent in directed migration were $2 \%$ for resting $\mathrm{NK}$ cells and 12\% for activated cells (Figure 1B). Thus, in this assay, resting NK cells almost completely lacked directionally persistent migration. The rest of the time, on average, $9 \%$ for resting NK cells and 17\% for activated NK cells, was spent in random movement (Figures 1B,E). Analysis showed that differences between resting and activated cells in the fractions of time spent in different modes of migration were statistically significant $(p<0.005)$.

Next, we compared the mean migration speeds of cells in different modes of migration and, as expected, the average mean speeds in TMAPs were considerably lower, $1.7 \pm 0.8 \mu \mathrm{m} / \mathrm{min}$ for resting and $1.7 \pm 0.8 \mu \mathrm{m} / \mathrm{min}$ for IL-2-activated $\mathrm{NK}$ cells $(p<0.05)$ compared to other modes of migration. In directed migration, the average mean speeds were $3.0 \pm 1.1$ and $\mathbf{2 . 5} \pm \mathbf{0 . 7} \mu \mathrm{m} / \mathrm{min}$ for resting and activated NK cells, respectively $(p<0.005)$. The random movement periods had average mean speeds of $2.6 \pm 1.1 \mu \mathrm{m} / \mathrm{min}$ for resting and $2.4 \pm 1.0 \mu \mathrm{m} / \mathrm{min}$ for activated NK cells (n.s; $p=0.09$, Figure S1 in Supplementary Material). Thus, resting NK cells had higher average mean speeds in both directed migration and random movement and, yet, had a lower overall average mean speed.

Taken together, the observed shift in the distribution of migration modes (Figure 1B) for resting and activated NK cells shows that IL-2 gives the NK cells a more migratory phenotype. This difference was reflected in a slight skewing of the distribution toward higher mean speeds for activated cells but even more pronounced when looking at transient migration behavior.

\section{MOTILE SCANNING AND SPEED IN CONTACT}

When in conjugation with target cells, resting and activated NK cells had comparable average mean speeds $(1.5 \pm 0.9 \mu \mathrm{m} / \mathrm{min}$ for resting NK cells and $\mathbf{1 . 6} \pm \mathbf{0 . 7} \mu \mathrm{m} / \mathrm{min}$ for activated NK cells, $p<0.005$ ) (Figure $4 \mathrm{~A})$. The average speed in attachment was slightly higher $(\mathbf{1 . 6} \pm \mathbf{0 . 8} \mu \mathrm{m} / \mathrm{min}$ for resting NK cells and $1.7 \pm 0.9 \mu \mathrm{m} / \mathrm{min}$ for activated NK cells) consistent with a more migratory morphology (Figure 4B). During attachment periods, in particular for activated NK cells, it was occasionally observed that NK cells dragged target cells along after termination of the conjugation phase (data not shown). While the difference in mean attachment speed was not statistically significant $(p=0.23)$, the difference in mean conjugation speed was $p<0.005$. This could be explained by differences in the distribution of measured speeds, and indeed, some NK cells were observed to move at a considerable speed while in conjugation with target cells.

\section{REFERENCE}

21. Khorshidi MA, Vanherberghen B, Kowalewski JM, Garrod KR, Lindstrom S, Andersson-Svahn H, et al. Analysis of transient migration behavior of natural killer cells imaged in situ and in vitro. Integr Biol (Camb) (2011) 3:770-8. doi:10.1039/ clib00007a 
Received: 05 September 2014; accepted: 05 September 2014; published online: 22 September 2014.

Citation: Frontiers Production Office (2014) Erratum:

Distinct migration and contact dynamics of resting and IL-2-activated human natural killer cells. Front. Immunol. 5:451. doi: 10.3389/fimmu.2014.00451
This article was submitted to NK Cell Biology, a section of the journal Frontiers in Immunology.

Copyright (c) 2014 Frontiers Production Office. This is an open-access article distributed under the terms of the Creative Commons Attribution License (CC $B Y)$. The use, distribution or reproduction in other forums is permitted, provided the original author(s) or licensor are credited and that the original publication in this journal is cited, in accordance with accepted academic practice. No use, distribution or reproduction is permitted which does not comply with these terms. 